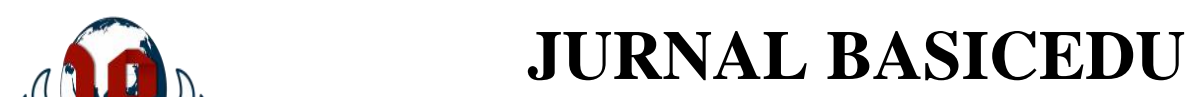

Volume 5 Nomor 5 Tahun 2021 Halaman 3073 - 3088

Research \& Learning in Elementary Education

https://jbasic.org/index.php/basicedu

PATLAWAN

\title{
The Effect of Problem-Based Learning Model during Pandemic On the Thematic Learning Outcomes of Students in Elementary School
}

\author{
Diana Falentina Simamora ${ }^{1 凶}$, Hisar Marulitua Manurung ${ }^{2}$ \\ University of HKBP Nommensen Pematangsiantar, Indonesia ${ }^{1,2}$ \\ E-mail: dianasimamora48@gmail.com ${ }^{1}$, hisarmanurung03@gmail.com ${ }^{2}$
}

\begin{abstract}
Abstrak
Penelitian ini bertujuan untuk mengetahui pengaruh model pembelajaran Problem Based Learning pada masa pandemi terhadap hasil belajar tematik siswa kelas IV SD Swasta HKBP Tomuan dengan Mata Pelajaran IPA pada tema 6 Citacitaku, subtema 1 dan Tujuanku, Pembelajaran 2. Penelitian Tindakan Kelas menggunakan 2 siklus dengan empat tahapan yaitu perencanaan, tindakan, observasi, dan refleksi. Subjek penelitian ini adalah siswa kelas IV SD Swasta HKBP Tomuan yang berjumlah 20 orang, sedangkan objek penelitian ini adalah hasil belajar tematik siswa dengan menerapkan model pembelajaran berbasis masalah. Teknik pengumpulan data adalah dengan mengamati dan melakukan pretest di awal pembelajaran dan posttest di akhir pembelajaran. Berdasarkan analisis data yang diperoleh pada siklus I dengan tidak menggunakan model problem based, hasil belajar 12 siswa mencapai KKM yaitu 60 sampai 75\%, dan 8 siswa tidak mencapai KKM yaitu <60\%. Pada siklus II dengan model problem based, 18 siswa mencapai KKM yaitu 60 sampai $85 \%$, dan 2 siswa tidak mencapai KKM yaitu $<60 \%$. Walaupun masih ada yang belum mencapai KKM, namun terjadi peningkatan dari tidak menggunakan model PBL (Problem Based Learning) menjadi menggunakan model PBL. Berdasarkan hasil penelitian menunjukkan bahwa penerapan model pembelajaran berbasis masalah dapat mempengaruhi hasil belajar tematik siswa kelas IV SD Swasta HKBP Tomuan.
\end{abstract}

Kata Kunci: Pengaruh PBL, Hasil Belajar, Tematik, Pandemi Covid-19.

\begin{abstract}
This study aims to determine the effect of the Problem Based Learning learning model during the pandemic on the thematic learning outcomes of students in grade IV Private Primary School HKBP Tomuan with Science Subjects on theme 6 My ideals, sub-theme 1 I and my ideals, learning 2. Types This research is Classroom Action Research using 2 cycles with four stages, namely planning, action, observation, and reflection. The subjects of this study were the fourthgrade students of HKBP Tomuan Private Elementary School, totaling 20 people, while the object of this research was the thematic learning outcomes of students by applying problem-based learning models. The technique of collecting data is by observing and conducting a pretest at the beginning of learning and a posttest at the end of learning. Based on the analysis of the data obtained in the first cycle by not using the problem-based model, the learning outcomes of 12 students reached the KKM, namely 60 to $75 \%$, and 8 students did not reach the KKM, which was $<60 \%$. In the second cycle using the problem-based model, 18 students achieved the KKM, which is 60 to $85 \%$, and 2 students did not reach the KKM, which is $<60 \%$. Although there are still those who do not reach the KKM, there has been an increase from not using the PBL (Problem Based Learning) model to using the PBL model. Based on the results of the study indicate that the application of problem-based learning models can affect the thematic learning outcomes of students in grade IV Private Elementary School HKBP Tomuan.
\end{abstract}

Keywords: The Influence of PBL, Learning Outcomes, Thematic, Covid-19 Pandemic.

Copyright (c) 2021 Diana Falentina Simamora, Hisar Marulitua Manurung

Corresponding author :

Email : dianasimamora48@gmail.com

DOI : https://doi.org/10.31004/basicedu.v5i5.1242

ISSN 2580-3735 (Media Cetak)

ISSN 2580-1147 (Media Online)

Jurnal Basicedu Vol 5 No 5 Tahun 2021

p-ISSN 2580-3735 e-ISSN 2580-1147 
3074 The Effect of Problem-Based Learning Model During Pandemic On the Thematic Learning Outcomes of Students in Elementary School - Diana Falentina Simamora, Hisar Marulitua Manurung

DOI : https://doi.org/10.31004/basicedu.v5i5.1242

\section{INTRODUCTION}

Education is a conscious effort to develop the potential of students' human resources by encouraging and facilitating teaching and learning activities. The content of the formulation of objectives in education must be complete (Siahaan, Haloho, et al., 2021). This means incorporating aspects of knowledge, attitudes, and skills. These three aspects of education are known as Bloom's taxonomy which includes three dimensions, namely (1) the cognitive domain which includes knowledge, understanding, application, analysis, and evaluation. (2) Affective domain which includes receiving responses, organizing, evaluating, and giving character. (3) The psychomotor domain goes through the stages of imitation, speculation, proposition, articulation, and naturalization (Armstrong, 2016). The purpose of Indonesian education is to form a complete human being, in the sense of developing individual potential in a balanced, optimal, and integral way. Therefore, education is needed for humans as a process of teaching and training to achieve these goals. A good teaching process must refer to the applicable curriculum (Manurung, n.d.).

Thematic learning is one of the lessons in the education curriculum in Indonesia at the basic level. Thematic learning is a teaching and learning approach that includes several subjects in one theme to provide a meaningful experience for students. Meaningful experience means that the child understands a concept that has been learned through direct experience and relates it to other concepts that have been understood. This is because thematic is one of the vehicles that are considered the most suitable for instilling knowledge, attitudes, and skills in students through the learning process (Indriani, 2016).

Because thematic learning in elementary schools is so important, teachers need to plan, understand, and implement thematic learning as much as possible, so that the concepts taught can be understood by students, so that students can participate and participate actively. learning process. However, in practice, thematic studies are not in line with what has been described above. As in some schools, we found some problems related to thematic learning. One of them is HKBP Tomuan Private Elementary School. Based on the results of observations or observations made in teaching and learning activities at the HKBP Tomuan Private Elementary School, especially science subjects in thematic learning in class IV, the use of the lecture method is more dominated and the activities are more focused on the teacher or student learning orientation is less. Student activities during learning only listen to the teacher's explanation and note things that are considered important. Students are less motivated to take lessons so students never ask the teacher. Especially now that it's a pandemic. Such circumstances can affect the lack of interest and motivation of students to learn, which results in poor student learning outcomes. Therefore, it is necessary to apply the right thematic learning model, one of which is by applying the Problem Based Learning model in learning.

In the Problem Based Learning (PBL) learning model, students will be formed in small groups and students can work together to solve problems that have been agreed upon by students and teachers related to the material. The application of the Problem Based Learning (PBL) learning model allows students to actively discuss with group members to solve problems and find their concepts. When teachers apply learning models, students often use various problem-solving procedures. Therefore, whether they like it or not, students must actively read and explain the material explanation from the teacher. In addition, they should actively seek additional information from various sources to resolve the issue under discussion. The learning process using this model can encourage and train students to think in their way, because by using this PBL model students will work alone, and feel what they will learn, in other words, students will know more about the material. . discussed. Students will have an active role, and the learning situation will be more enjoyable so that the learning objectives to be achieved can be achieved easily as expected.

According to Lovisia,(2018) the learning model is a plan or a pattern that is used as a guide in planning classroom learning or learning in tutorials and to determine learning tools including books, films, computers, curriculum, and teaching aids others (Sulfemi \& Mayasari, 2019). A learning model is a form of learning that 
is illustrated from beginning to end which is presented specifically by the teacher. In other words, the learning model is a wrapper or frame from the application of an approach, method, and learning technique.

According to (Wenger, 2014) suggests "The term teaching model refers to a particular approach to instruction that includes its goals, syntax, environment, and management system." The term teaching model refers to a particular learning approach including its objectives, syntax, environment, and management system.

The term learning model approach includes a comprehensive or comprehensive learning model. By using this learning model, the teacher guides students to make a problem-solving plan at the activity stage, the teacher provides examples of using the skills and strategies needed to complete the task. Teachers use flexible and self-contained classrooms for student exams (Purba, 2015). The function of the learning model is that the teacher can inspire students to form information, ideas, skills, ways of thinking, and articulate ideas. The learning model can be a guide for designers and teachers to learn about teaching and learning activities (Purba, 2015).

Problem-based learning models include questioning or problem solving, focusing on interdisciplinary relationships, authentic inquiry, collaboration, and producing works and demonstrations (Cowden \& Santiago, 2016). Problem-based learning is not designed to help teachers provide informative information to students. Problem-based learning is learning that uses real (authentic) problems that are not structured and open as a context for students to develop problem-solving and critical thinking skills and build new knowledge. In contrast to conventional learning which makes real problems as the application of concepts, problem-based learning makes real problems a trigger for students' learning processes before they understand formal concepts (Ananda \& Fadhilaturrahmi, n.d.).

According to Fadhilaturrahmi, (2017) problem-based learning is an innovation in learning because, in PBL, students' thinking skills are truly optimized through a systematic group or teamwork process, so that students can empower, hone, test, and develop their thinking skills effectively. sustainable. Ibrahim and Nur (2000:2) suggest that problem-based learning is one of the learning models used to stimulate students' higherorder thinking in real-world problem-oriented situations, including learning how to learn.

According to (Widyatiningtyas et al., 2015), the objectives of problem-based learning in detail are: Helping students develop critical thinking and problem-solving skills, learning various adult roles through student involvement in real experiences, and becoming autonomous students.

The characteristics of problem-based learning according to (Kassymova et al., 2020) are as follows: Problems are used as the beginning of learning, usually, the problems used are real-world problems that are presented in an ill-structured manner, problems usually require multiple perspectives. perspective), the problem of making students get learning in new learning areas, giving priority to self-directed learning, utilizing various sources of knowledge, not from one source only. The search, evaluation, and use of this knowledge are key. collaborative, communicative, and cooperative learning. Students work in groups, interact, teach each other (peer teaching) and make presentations (Siahaan, Lumbangaol, et al., 2021).

According to (Little, 2013) there are 7 steps of the problem-based learning process (PBL) as follows: Step 1: Clarify terms and concepts that are not yet clear. Ensure that each member understands the various terms and concepts involved in the problem. Step 2: Formulate the problem. The phenomenon that exists in the problem demands an explanation of what relationships occur between the phenomena. Step 3: Analyze the problem. Members issue knowledge regarding what members already have about the problem. There was a discussion that discussed factual information and information that was in the minds of members. Step 4: Organize ideas systematically analyze them deeply. The parts that have been analyzed are seen to be related to each other, grouped, which are mutually supportive, which are contradictory, and so on. Step 5: Formulate learning objectives. Formulate learning objectives associated with the analysis of the problems made. Step 6: Seek additional information from other sources (outside group discussions). Look for additional information 
and determine where to look. Each member must be able to learn on their own effectively, to obtain relevant information. Step 7: Synthesize (combine) and test new information, and generate reports for the class.

Thematic learning is a learning model that combines various learning materials from various competency standards and basic competencies from one or more subjects. The implementation of this research can be done through three approaches, namely: determination based on the relevance of competency standards and basic competencies, themes, and problems identified (Nurmeilana et al., 2021). Thematic learning is learning that combines several subjects into one theme, thematic learning in elementary schools emphasizes more on student activities during learning so that with active student involvement, learning outcomes will be better and learning will be more useful.

According to (Ain, 2017) the characteristics of thematic learning are as follows:

Active and Student-Centered.

Thematic learning is student-centered, this is following the modern learning approach which places more students as learning subjects while the teacher acts more as a facilitator, namely providing facilities for students to carry out learning activities.

Provide hands-on experience.

Thematic learning can provide direct experience to students. With this direct experience, students are faced with something real (concrete) as a basis for understanding more abstract things.

The separation of subjects is not very clear. In thematic learning, the separation between subjects is not so clear. The focus of learning is directed to the discussion of the themes that are most closely related to the lives of students.

Presenting concepts from various subjects.

Thematic learning presents concepts from various subjects in one learning process. Thus, students can solve problems faced in everyday life.

Flexible.

Thematic learning is flexible (flexible) where teachers can relate teaching materials from one subject to other subjects, even linking them to the lives of students and the environmental conditions in which schools and students are located.

Learning outcomes according to the interests and needs of students Students are allowed to optimize their potential according to their interests and needs.

Using the principle of learning while playing and having fun (joyful learning).

Integrated thematic learning serves to provide convenience for students to understand and explore the concepts of material incorporated in the theme and increase the enthusiasm for learning because the material studied is real (contextual) and meaningful material for students (Khoeriyah \& Mawardi, 2018)

The objectives of integrated thematic learning are: It is easy to focus on one particular theme or topic. Learn knowledge and develop various subject competencies in the same theme. Have a deeper and more effective understanding of the subject matter. Develop better language competence by linking various other lessons with students' personal experiences. They are more passionate about learning because they can communicate in real situations such as: telling stories, asking questions, writing while learning other subjects. More feel the benefits and meaning of learning because the material is presented in the context of a clear theme. Teachers can save time because the subjects that are presented in an integrated manner can be prepared at once and given in 2 or 3 meetings or even more or enrichment. Students' character and morals can be grown and developed by raising many character values according to the situation and conditions.

Science learning is a series of concepts and conceptual schemes that are related to each other. Science learning is the result of experimentation and observation and is useful for further observations and experiments. Science learning is a learning activity designed to provide a learning experience that involves 
mental and physical processes through interactions between students and teachers, the environment, and other learning resources in achieving Basic Competencies (KD) (Nurhalizha, 2017)

Science learning is the science of natural phenomena through direct observation or observation. By studying science, they are expected to experience students' curiosity to develop questioning skills, find evidence-based answers, and develop scientific thinking. Science is one of the teaching materials with a very broad scope. To learn, it is necessary to pay attention to that level. The scope of science studies at SD/MI includes the following aspects: 1 . Includes observations that the motion of an object is influenced by its shape and size, 2. Describes the results of observations of the effects of heat energy, motion, vibration in everyday life, and 3. Identify sources and uses of energy (Haryadi \& Pujiastuti, 2019).

The learning process causes changes in everyone's behavior because of these efforts. Learning is not the ultimate goal, but a means to an end. Learning theories include descriptive and prescriptive learning theories, behavioristic learning theories, cognitivist learning theories, humanistic learning theories, and constructivist learning theories. According to (Burhanudin \& Wahyuni, 2020) revealed that the characteristics of learning include: Learning is characterized by a change in behavior (change behavior). This means, that the results of learning can be observed from behavior, which means that it can be seen by changes in behavior, and from not knowing to know, and not being skilled to being skilled. Behavioral changes are relatively permanent. Changes in behavior do not have to be immediately observable during the learning process, these changes in behavior are potential. Changes in behavior are the result of practice or experience. The experience or practice can provide reinforcement.

Factors that influence learning include Intrinsic Factors and Intrinsic Factors. Learning outcomes are the most important part of learning. Learning outcomes are skills that students acquire after receiving a learning experience. These abilities include cognitive, affective, and psychomotor aspects. Learning outcomes can be seen through evaluation activities that aim to obtain evidence-based data that will indicate the level of students' abilities in achieving learning objectives. Learning outcomes as an indicator of the achievement of learning objectives in the classroom can not be separated from the factors that affect the learning outcomes themselves, namely internal and external factors.

To support children's cognitive development, appropriate and relevant learning models are needed. In fact, in thematic learning, it is necessary to use a learning model that is considered suitable for learning at elementary school age, namely the Problem Based Learning (PBL) Model (Manurung, 2021). The PBL model is a learning model that tells contextual problems that can stimulate students to learn and emphasizes providing problems that students can solve through group work or in learning experiences. The application of the PBL model can be the right solution that is applied in thematic learning. PBL is a model that develops higher-order thinking skills. This is because thematic learning equips students to think critically and objectively. One of the materials that can be studied using the PBL model is "Theme 6 My Aspirations, Subtheme 1 I and My Dreams, Learning 2". If the PBL model is applied in science learning, then in this study the researcher will look at the effect of the PBL model on the learning outcomes of fourth-grade students.

This framework can be illustrated in the concept map below: 


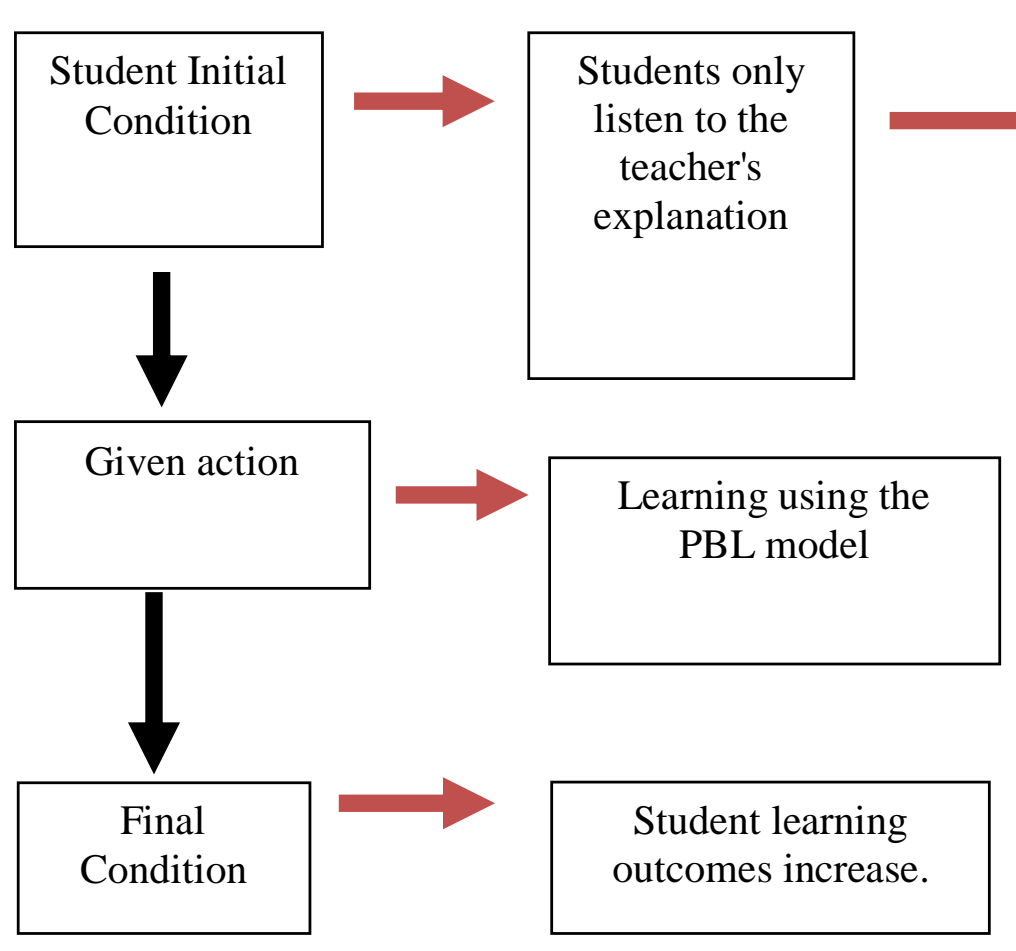

\section{RESEARCH METHOD}

The type of research used is Classroom Action Research (CAR). According to (Mulia \& Suwarno, 2016) CAR is action research carried out by teachers as well as researchers in their class or together with other people (collaboration) by designing, implementing, and reflecting on collaborative and participatory actions that aim to improve or improve the quality of the learning process in the classroom through a certain action in a cycle. CAR is action research conducted to improve the quality of classroom practice.

The subjects in this study were the fourth-grade students of Private Elementary School HKBP Tomuan Pematangsiantar City, totaling 20 students consisting of 15 female students and 5 male students. Meanwhile, the purpose of this research is the thematic learning outcomes of students by applying a problem-based learning model. The variables in this study are the application of the Problem-Based Learning Model (variable $\mathrm{x}$ ) and the learning outcomes of fourth-grade students (variable y).

In the Kemmis and Mc. Taggart, in one cycle or cycle, consists of four components as only implemented by Lewin, namely: 1) planning, 2) action, 3) observation, 4) reflection. According to Kemmis and Mc Taggart's model, at the acting stage, observing (observing) is used as a unit. This is because the two stages are because between the implementation of acting and observing are two activities that cannot be separated (Sanjaya, 2016). 


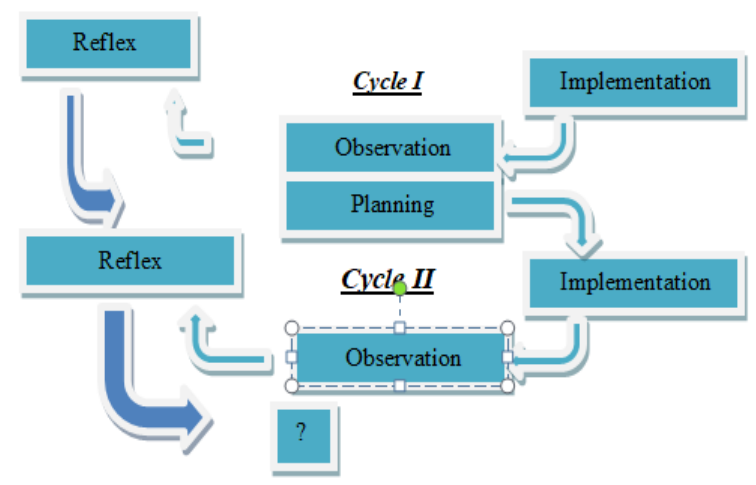

To obtain data in this study, the authors carried out data collection techniques, namely by observation and documentation.

The method of data analysis in this study was carried out using quantitative analysis methods. Quantitative methods of research data in the form of numbers and analysis using statistics. Data analysis is calculated using the following formula:

Quantitative Method

This quantitative analysis was conducted to see the improvement in learning outcomes using a written test. Data analysis is calculated using the following formula:

To calculate the average value

$\mathrm{X}=\frac{\sum \mathrm{X}}{n}$

Information:

$\mathrm{X}=$ Grade average

$\sum \mathrm{x}=$ Total student test scores

$\mathrm{n}=$ Number of students taking the test

For presentation

$\mathrm{P}=\mathrm{f} / \mathrm{N} \times 100 \%$

Information:

$\mathrm{f}=$ Frequency being searched for percentage

$\mathrm{N}=$ Number of frequencies / number of individuals

$\mathrm{P}=$ Percentage sought

Qualitative analysis

Qualitative analysis was used to analyze data about student learning activities during the learning process using the PBL model. The levels of mastery are:

\begin{tabular}{cc}
\hline Level of success $(\%)$ & Criteria \\
\hline $86-100 \%$ & Very Good \\
\hline $80 \%-89 \%$ & Good \\
\hline $65-79 \%$ & Enough \\
\hline $55 \%-64 \%$ & deficient \\
\hline $0-55 \%$ & fail \\
\hline
\end{tabular}

In this study using instruments in the form of observation sheets and test questions. The indicator of success in this research is the improvement of student learning outcomes in thematic learning from cycle to cycle. The indicator of success is marked by an increase in student learning outcomes with the achievement of the Minimum Completeness Criteria (KKM) for thematic learning with a score of $\geq 60$ reaching $70 \%$. 

of Students in Elementary School - Diana Falentina Simamora, Hisar Marulitua Manurung DOI : https://doi.org/10.31004/basicedu.v5i5.1242

\section{FINDINGS AND DISCUSSION}

Based on the results of observations made in this study, starting from planning activities, pre-cycle activities and continued with corrective actions in cycle I, and continued in cycle II, where the implementation time span of pre-cycle and first-cycle activities was in early October 2020 for 1 week and continued in cycle II in the second week of October 2020. From the results of the analysis in cycle I the results obtained from the achievement of teacher and student activities, student motivation and student learning outcomes are still not as expected. In the first cycle the teacher took corrective action but the teacher was not maximal in delivering learning, the teacher had not seen the motivation and maximum use of learning media, the students in this first cycle did not appear enthusiastic, there were still some students who wanted to respond to the teacher's questions and were less independent and confident in group work or in presentations. Therefore, in cycle II the teacher began to make maximum improvements starting from planning, preparing lesson plans, learning materials, LKPD, observation sheets, learning media and evaluation sheets. In this second cycle, the teacher is more optimal in carrying out activities during the learning process by using the Problem Based Learning model with the help of Sway media. Meanwhile, students' learning motivation in participating in learning activities has also increased, seen here students are very enthusiastic and respond to teacher questions quickly and enthusiastically, and students are more active, disciplined, responsible and confident in doing assignments and presenting the results of discussions, although there are less maximum in group work. Meanwhile, the results of the analysis of student learning mastery in cycle II have also been as expected, where learning outcomes have improved significantly compared to cycle I.

As previously explained, it can be seen that through learning with the Problem Based Learning model and Sway media, the learning motivation of grade IV students at the Private Elementary School HKBP Tomuan Pematangsiantar City for the 2020/2021 academic year has increased. We can see this from the following results:

\section{a. Student Learning Motivation Research Results}

The results of observations in the first cycle are used as a reference for improvements in the second cycle so that students' learning motivation increases better in the second cycle. The following are the results of the thematic learning observations carried out by teachers from cycle I to cycle II.

Table 2. Results of Observation of Student Activities in Applying Problem Based Learning and Media Sway Methods

\begin{tabular}{cccccccc}
\hline Number & Meeting & Pre Cycle & $\begin{array}{c}\text { Student } \\
\text { Cycle } \\
\text { I }\end{array}$ & $\begin{array}{r}\text { Student } \\
\text { Cycle } \\
\text { II }\end{array}$ & Student \\
\hline 1. & $\begin{array}{c}\text { Meeting } \\
\text { I }\end{array}$ & $37,9 \%$ & 7 & $56 \%$ & 12 & $86 \%$ & 16 \\
\hline 2. & $\begin{array}{c}\text { Meeting } \\
\text { II }\end{array}$ & $48,3 \%$ & 10 & $72 \%$ & 15 & $100 \%$ & 20 \\
\hline & Average & $43,1 \%$ & 9 & $64 \%$ & 13 & $93 \%$ & 18 \\
\hline
\end{tabular}

The data above shows that the teacher observes student activities during thematic learning, in terms of activity, discipline, responsibility and self-confidence, with observations showing an increase from cycle I to cycle II obtained $100 \%$. 

of Students in Elementary School - Diana Falentina Simamora, Hisar Marulitua Manurung DOI : https://doi.org/10.31004/basicedu.v5i5.1242

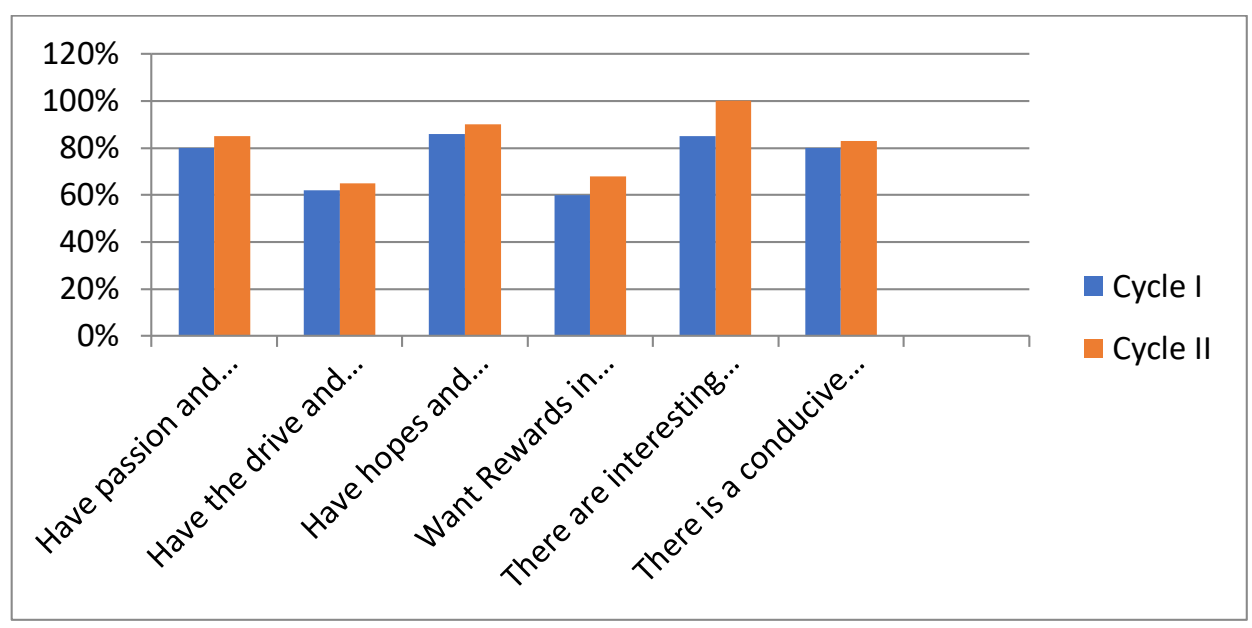

Figure 1. Diagram of the Average Motivation Score of Each Indicator

Student learning motivation consists of 6 indicators, namely: 1) There is a desire and desire to succeed, 2) There is encouragement and need in learning, 3) There are hopes and aspirations for the future, 4) There is appreciation in learning, 5) There are interesting activities in learning. , and 6) The existence of a conducive learning environment. Students' learning motivation data was obtained through filling out learning motivation questionnaires after students followed the learning process, namely in cycle I and cycle II.

Based on the results of the study, in learning that applies the Problem Based Learning model with Sway media there is student learning motivation as in the diagram above that in the first cycle has the desire and desire to succeed, $79.30 \%$, in the second cycle $86 \%$, has the drive and need to learn in the second cycle. Cycle I $62.06 \%$ and cycle II $66 \%$, have future hopes and aspirations in cycle I $89.65 \%$ and cycle II $93 \%$, there is an appreciation in learning cycle I $62,06 \%$ and cycle II $69 \%$, interesting activities in learning cycle I $86.20 \%$ and cycle II $97 \%$, conducive learning environment, $82.76 \%$ and cycle II $86 \%$.

Cycle I and cycle II on average experienced an increase in learning motivation, the highest point in the application of students' online learning with problem based learning (pbl) and media sway learning models was at the point of interesting activities in learning, namely 97\%, and followed by on motivation to have hopes and aspirations for the future that is $93 \%$ and a conducive learning environment is $86 \%$, this shows that in this pandemic they prefer when studying there are interesting activities and a conducive learning environment so that they are easy to understand lessons .

As previously explained, it can be seen that through learning with the Problem Based Learning model and Sway media, the learning motivation of grade IV students at the Private Elementary School HKBP Tomuan Pematangsiantar City for the 2020/2021 academic year has increased. We can see this from the following results:

\section{Increasing Student Learning Motivation, including;} Increasing Teacher and Student Activities

Table 3. Observation results of activities in applying the Problem Based Learning Method and Sway . media

\begin{tabular}{cccccccc}
\hline Number & Meeting & $\begin{array}{c}\text { Cycle } \\
\text { I }\end{array}$ & Student & $\begin{array}{c}\text { Cycle } \\
\text { II }\end{array}$ & Student & Information & Qualification \\
\cline { 1 - 5 } 1. & $\begin{array}{c}\text { Meeting } \\
\text { I }\end{array}$ & $56 \%$ & 12 & $86 \%$ & 16 & Increase & Very Good \\
\cline { 1 - 6 } 2. & $\begin{array}{c}\text { Meeting } \\
\text { II }\end{array}$ & $72 \%$ & 15 & $\begin{array}{c}100 \\
\%\end{array}$ & 20 & Increase & Very Good \\
\cline { 1 - 5 } & Avarage & $64 \%$ & 13 & $93 \%$ & 19 & & \\
\hline
\end{tabular}


The data above shows that the teacher observes student activities during thematic learning, in terms of activity, discipline, responsibility and self-confidence, with observations showing an increase from cycle I to cycle II has reached $100 \%$.

Student learning activities that have increased also cannot be separated from better interactions between fellow students in each group and also interactions between teachers and students. Student learning activities seem to have increased. This is in line with the results of other studies which state that the application of the Problem Based Learning model can improve student learning activities (Simamora et al., 2017)

Students' learning motivation in pre-action when the Problem Based Learning model has not been used the average student motivation is $43.1 \%$ with a description of 13 students being active in learning with a percentage of $44.8 \%$ and 16 students being inactive with a percentage of $55.2 \%$. Student learning motivation in the first cycle when the Problem Based Learning model was used, the average student motivation was 64\% with a description of 19 students completing with a $65.5 \%$ completeness percentage and 10 students incomplete with $34.5 \%$ completeness percentage. At the time of Cycle II, after the Problem Based Learning model was used, the average student motivation was $93 \%$ with a description of 27 students completing with a percentage of completeness $93.1 \%$ and 2 students incomplete with a percentage of completeness $6.9 \%$ From the diagram above, it shows that there is an increase in student motivation before the Problem Based Learning model with Sway media is used and before it is used. When the method has not been used, the level of student motivation who has completed shows $43.1 \%$ and after the method is used the level of motivation of students who completes shows the number 64\% in Cycle I and 93\% in Cycle II. From these results indicate an increase in an increase in motivation. Thus, it is in line with the opinion put forward by Deka Candra which states that the Problem Based Learning model can increase learning motivation.

Table.4. Increased activities of Teachers and Students

\begin{tabular}{cccccc}
\hline Activity & Cycle 1 & Criteria & Cycle II & Criteria & Rangking \\
\hline Teacher & 80 & Good & 97 & Very Good & 7 \\
\hline Student & 64 & Enough & 93 & Very Good & 29 \\
\hline
\end{tabular}

\section{Improving Student Motivation Indicators}

Table 5. The results of increasing student motivation according to Sardiman (2001: 81) indicators of learning motivation are as follows:

\begin{tabular}{ccccc}
\hline Number & MOTIVATION INSTRUMENTS & Cycle I & Cycle II & Motivation \\
\hline 1 & $\begin{array}{c}\text { Have passion and desire to } \\
\text { succeed }\end{array}$ & $79,30 \%$ & $86 \%$ & \\
\hline 2 & $\begin{array}{c}\text { Have encouragement and } \\
\text { need in learning }\end{array}$ & $62,06 \%$ & $66 \%$ & \\
\hline 3 & Have hopes and dreams for the \\
future & $89,65 \%$ & $93 \%$ & \\
\hline 4 & Want rewards in learning & $62,06 \%$ & $69 \%$ & Highest \\
\hline 5 & There are interesting activities in \\
& $86,20 \%$ & $97 \%$ & & \\
\hline
\end{tabular}



of Students in Elementary School - Diana Falentina Simamora, Hisar Marulitua Manurung DOI : https://doi.org/10.31004/basicedu.v5i5.1242

\begin{tabular}{cccc}
\hline 6 & There is a conducive learning & $82,76 \%$ & $86 \%$ \\
environment.
\end{tabular}

Based on the table above that the motivation of students during this pandemic in implementing learning by applying the Problem Based Learning (PBL) method with Sway media is that there are interesting activities in learning that is $97 \%$, this indicates that students want interesting learning activities because they feel bored with learning that has only done questions from the teacher.

\section{b. Increasing the Implementation of Problem Based Learning (PBL) Learning Models with Sway} media.

Table 6. Results of Application of PBL Learning Model and Media Sway

\begin{tabular}{|c|c|c|c|c|}
\hline Number & Syntax & Cycle I & Cycle II & Information \\
\hline 1 & Student orientation to problems & & & $\begin{array}{l}\text { Still not } \\
\text { maximal in }\end{array}$ \\
\hline 2 & Organizing students to learn & $80 \%$ & $97 \%$ & investigation \\
\hline 3 & $\begin{array}{l}\text { Guiding individual and group } \\
\text { investigations }\end{array}$ & & & $\begin{array}{l}\text { individual or } \\
\text { group }\end{array}$ \\
\hline 4 & Develop and present the work & & & \\
\hline 5 & $\begin{array}{c}\text { Analyze and evaluate problem } \\
\text { solving }\end{array}$ & & & \\
\hline
\end{tabular}

Based on the table above, cycle I $80 \%$ and cycle II $97 \%$ shows that in this cycle each student has been active in the learning process but there are still shortcomings, namely at the stage of organizing students to learn there are still few students who ask the material presented and it is still difficult to form. group. At the stage of guiding individual and group investigations, the students in the group have not been maximal in gathering information related to problems in the LKPD (Student Worksheet). At the stage of developing and presenting the work, only a few other students asked questions or responded to the work of the presenter. At the stage of analyzing and evaluating the problem solving process, students still find it difficult to conclude the final results of learning (Siahaan, Manurung, et al., 2021). In cycle II, student learning activities increased compared to cycle I with an average score of $93 \%$ for both observers in the active category. This increase was caused by several things including students getting used to the learning applied by the teacher. At the stage of organizing students to learn, students begin to actively ask the material presented by the teacher. At the stage of guiding individual and group investigations, students have been actively collecting information related to the problems presented in the LKPD. At the stage of developing and presenting students' work, they are already actively asking questions or responding to the work of the presenter. 

of Students in Elementary School - Diana Falentina Simamora, Hisar Marulitua Manurung DOI : https://doi.org/10.31004/basicedu.v5i5.1242

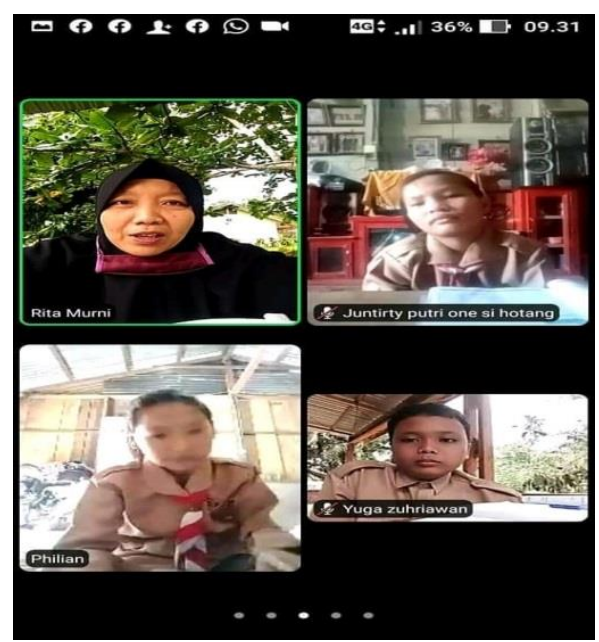

Photo.1. Cycle II Online Learning Activities

Figure 1 shows learning in cycle 1 with the application of problem based learning learning methods, not many students have shown activeness and motivation, because they can't focus yet, they observe the media sway displayed by the teacher, although there are some who are active but have not reached more than $75 \%$ so that learning is carried out in cycle II.

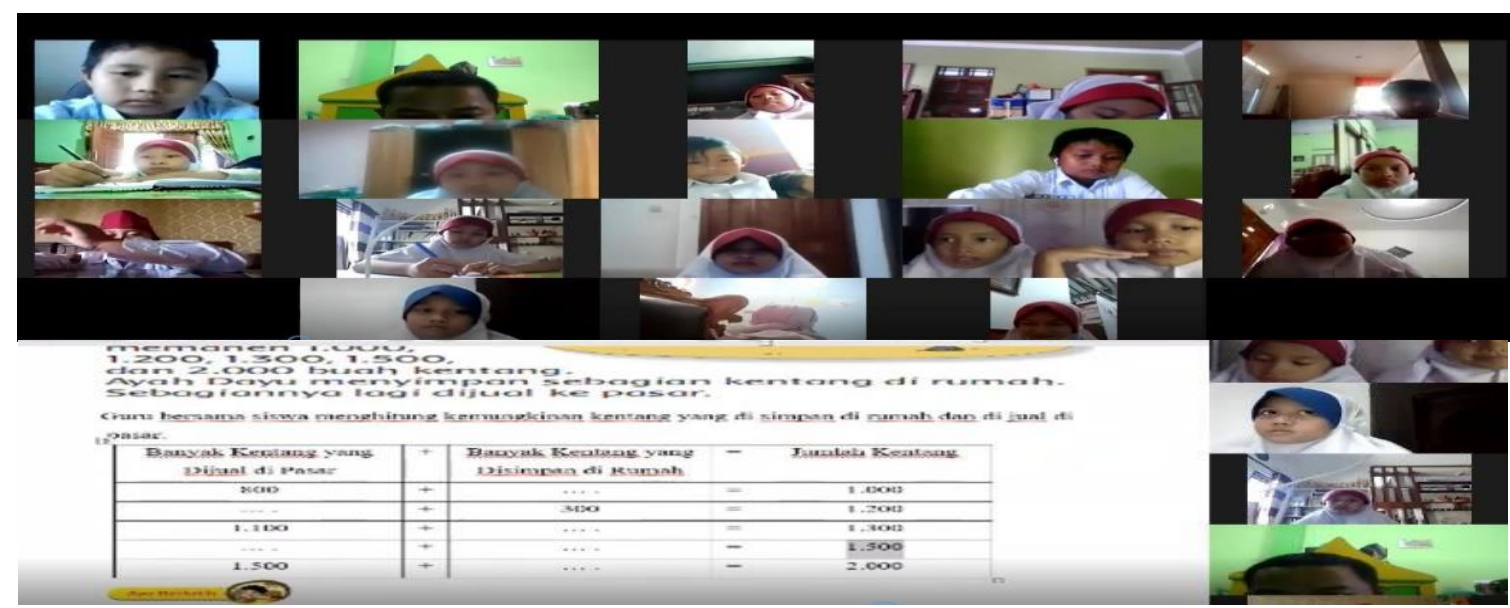

Photo.2. Cycle II Online Learning Activities

\section{Teacher and Student Activities}

The increase in the results of observing teacher and student activities in carrying out learning in cycles I and II can be seen in graph 1. From the diagram it can be seen that the teacher's ability to convey learning using the problem based learning learning model with Sway media has increased from cycle I to cycle II. In the first cycle, the teacher in conveying the learning process has not reached the predetermined target. The success rate in conveying the learning process is $80 \%$ (criteria: good) While in the second cycle, there is an increase in conveying the learning process because the teacher has made improvements in the learning process. In the second cycle, the achievement level was 97\% (criteria: very good). Meanwhile, on student activity, it can be seen that there was an increase in student activity from cycle I to cycle II. From the diagram, it can be seen that student activities during learning using the problem based learning model using Sway media also experienced an increase from the first cycle of $64 \%$ (criteria: less) to the second cycle of $93 \%$ (Criterion: very good). 

of Students in Elementary School - Diana Falentina Simamora, Hisar Marulitua Manurung DOI : https://doi.org/10.31004/basicedu.v5i5.1242

Table 7. Results of Increasing Student and Teacher Activities from Cycle I to Cycle

\begin{tabular}{cccccc}
\hline Activity & Cycle 1 & Criteria & Cycle II & Criteria & Rangking \\
\hline Teacher & 80 & Good & 97 & Very Good & 7 \\
\hline Student & 64 & Enough & 93 & Very Good & 29 \\
\hline
\end{tabular}

\section{Results of Student Motivation Indicators}

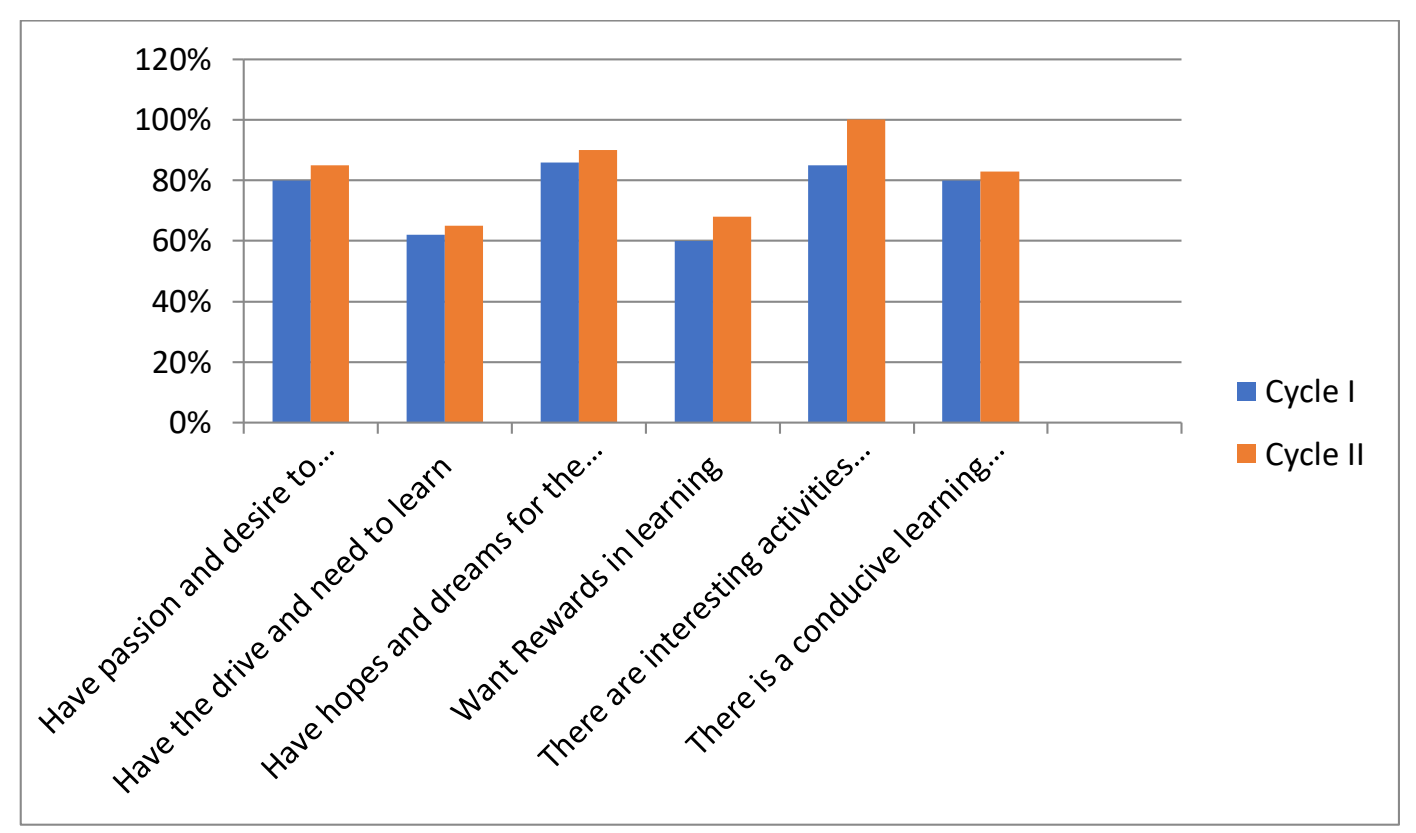

Figure 2. Diagram of the Average Motivation Score of Each Indikator

Student learning motivation consists of 6 indicators, namely: 1) There is a desire and desire to succeed, 2) There is encouragement and need in learning, 3) There are hopes and aspirations for the future, 4) There is appreciation in learning, 5) There are interesting activities. in learning, and 6) The existence of a conducive learning environment. Students' learning motivation data was obtained through filling out learning motivation questionnaires after students followed the learning process, namely in cycle I and cycle II.

Based on the results of the study, in learning that applies the Problem Based Learning model with Sway media there is student learning motivation as in the diagram above that in the first cycle has the desire and desire to succeed, $79.30 \%$, in the second cycle $86 \%$, has the drive and need to learn in the second cycle. the first cycle $62.06 \%$ and the second cycle $66 \%$, have hopes and aspirations for the future in the first cycle $89.65 \%$ and the second cycle $93 \%$, the appreciation in learning cycle I $62,06 \%$ and the second cycle $69 \%$, the existence of interesting activities in learning cycle I $86.20 \%$ and cycle II 97\%, conducive learning environment, $82.76 \%$ and cycle II $86 \%$. Improving student learning outcomes is a process of developing teacher professional competencies (Hartini, 2019). The results of this study prove that the professional competence of teachers through research (Supriyanto et al., 2019).

Cycle I and cycle II on average experienced an increase in learning motivation, the highest point in the application of students' online learning with problem based learning (pbl) and media sway learning models was at the point of interesting activities in learning, namely $97 \%$, and followed by on motivation to have 
hopes and aspirations for the future that is $93 \%$ and a conducive learning environment is $86 \%$, this shows that in this pandemic they prefer when studying there are interesting activities and a conducive learning environment so that they are easy to understand lessons. Students' self-development in basic education can require the help of guidance and counseling teachers (Prasetiawan \& Supriyanto, 2016). Guidance and counseling services in basic education are carried out through the media during the Covid-19 pandemic (Kurniawati et al., 2020)

\section{CONCLUSION}

The problem in this study is the low thematic learning outcomes of students, especially in science subjects. This study aims to determine the effect of the Problem Based Learning learning model during the pandemic on the thematic learning outcomes of students in grade IV SD Private HKBP Tomuan with Science Subjects on theme 6 My ideals, sub-theme 1 I and my ideals, learning 2. Types of research This is Classroom Action Research using 2 cycles with four stages, namely planning, action, observation and reflection. The subjects of this study were the fourth grade students of HKBP Tomuan Private Elementary School, which amounted to 20 people. While the object of this research is the thematic learning outcomes of students by applying a problem-based learning model. The technique of collecting data is by observing and conducting pretest at the beginning of learning and posttest at the end of learning. Based on the analysis of the data obtained in the first cycle by not using the problem-based model, the learning outcomes of 12 students reached the KKM, namely 60 to $75 \%$ and 8 students did not reach the KKM, which was $<60 \%$. In the second cycle using the problem-based model, 18 students achieved the KKM, which is 60 to $85 \%$, and 2 students did not reach the KKM, which is $<60 \%$. Although there are still those who do not reach the KKM, there has been an increase from not using the PBL model to using the PBL model. The results of the study indicate that the application of the problem-based learning model can affect the thematic learning outcomes of students in grade IV SD Private HKBP Tomuan with Science Subjects on theme 6 My ideals, sub-theme 1 I and my ideals, learning 2.

\section{ACKNOWLEDGEMENTS}

Thanks to HKBP Nommensen Pematangsiantar University and LPPM HKBP Nommensen University who have supported this research.

\section{REFRENCE}

Ain, N. (2017). Holistic Thematic Learning In The Elementary School: Is It Thematic And Holistic. Advances In Social Science, Education And Humanities Research, 158, 919-928.

Ananda, R., \& Fadhilaturrahmi, F. (N.D.). Analisis Kemampuan Guru Sekolah Dasar Dalam Implementasi Pembelajaran Tematik Di SD. Jurnal Basicedu, 2(2), 11-21.

Armstrong, P. (2016). Bloom's Taxonomy. Vanderbilt University Center For Teaching.

Burhanudin, F. A., \& Wahyuni, A. (2020). Implementation Of Permendikbud No. 20 Article 8 Paragraph 4 Of 2018 At SD Muhammadiyah 10 Balongbendo. Indonesian Journal Of Education Methods Development, 11.

Cowden, C. D., \& Santiago, M. F. (2016). Interdisciplinary Explorations: Promoting Critical Thinking Via Problem-Based Learning In An Advanced Biochemistry Class. Journal Of Chemical Education, 93(3), 464-469. 
3087 The Effect of Problem-Based Learning Model During Pandemic On the Thematic Learning Outcomes of Students in Elementary School - Diana Falentina Simamora, Hisar Marulitua Manurung DOI : https://doi.org/10.31004/basicedu.v5i5.1242

Fadhilaturrahmi, F. (2017). Peningkatan Hasil Belajar Siswa Pada Materi Jaring-Jaring Balok Dan Kubus Dengan Pendekatan Contextual Teaching And Learning (CTL) Siswa Kelas IV SDN 05 Air Tawar Barat. Jurnal Basicedu, 1(1), 1-9.

Hartini, S. (2019). Kompetensi Profesional Guru Dalam Meningkatkan Motif Berprestasi Peserta Didik: Studi Di SDN Karangpucung 04 Dan SDN Karangpucung 05 Kabupaten Cilacap. Indonesian Journal Of Education Management \& Administration Review, 3(1), 71-76.

Haryadi, R., \& Pujiastuti, H. (2019). Discovery Learning Based On Natural Phenomena To Improve Students' Science Process Skills. Jurnal Penelitian \& Pengembangan Pendidikan Fisika, 5(2), 183-192.

Indriani, F. (2016). Kompetensi Pedagogik Mahasiswa Dalam Mengelola Pembelajaran Tematik Integratif Kurikulum 2013 Pada Pengajaran Micro Di Pgsd Uad Yogyakarta. Elementary School: Jurnal Pendidikan Dan Pembelajaran Ke-SD-An, 3(1).

Kassymova, G., Akhmetova, A., Baibekova, M., Kalniyazova, A., Mazhinov, B., \& Mussina, S. (2020). ELearning Environments And Problem-Based Learning. International Journal Of Advanced Science And Technology, 29(7), 346-356.

Khoeriyah, N., \& Mawardi, M. (2018). Penerapan Desain Pembelajaran Tematik Integratif Alternatif Berbasis Kearifan Lokal Untuk Meningkatkan Hasil Dan Kebermaknaan Belajar. Mimbar Sekolah Dasar, 5(2), $63-74$.

Kurniawati, E. N., Khasanah, U., \& Lestari, E. (2020). Penerapan Problem Based Learning Untuk Meningkatkan Keaktifan Belajar Siswa Melalui Media Gambar Pada Pembelajaran Matematika Siswa Kelas I Di Sd Muhammadiyah Trayu.

Little, S. (2013). Preparing Tertiary Teachers For Problem-Based Learning. In The Challenge Of ProblemBased Learning (Pp. 125-132). Routledge.

Lovisia, E. (2018). Pengaruh Model Pembelajaran Inkuiri Terbimbing Terhadap Hasil Belajar. SPEJ (Science And Physic Education Journal), 2(1), 1-10.

Manurung, H. M. (N.D.). Pengaruh Modul Kimia Umum Berbasis Problem Based Learning (PBL) TERHADAP PENGUASAAN KONSEP MAHASISWA PADA MATERI STOIKIOMETRI. Quantum: Jurnal Inovasi Pendidikan Sains, 12(1), 82-90.

Manurung, H. M. (2021). Model Pembelajaran Kimia Kreatif Berbasis PBL Menggunakan Macromedia Flash.

Mulia, D. S., \& Suwarno, S. (2016). PTK (Penelitian Tindakan Kelas) Dengan Pembelajaran Berbasis Kearifan Lokal Dan Penulisan Artikel Ilmiah Di Sd Negeri Kalisube, Banyumas. Khazanah Pendidikan, 9(2).

Nurhalizha, I. (2017). Peningkatan Hasil Belajar IPA Dengan Menggunakan Metode Eksperimen Pada Siswa Kelas V MIN 4 Aceh Besar. UIN Ar-Raniry Banda Aceh.

Nurmeilana, R., Nulhakim, L., \& Suparno, S. (2021). The Development Of Thematic Magnetic Board (Pamantik) Media In Thematic Learning For Class Iii Primary School. Jurnal Ilmiah Sekolah Dasar, 4(4).

Purba, Y. O. (2015). Perbedaan Kemampuan Berpikir Kreatif Dan Pemecahan Masalah Matematis Siswa Yang Diberi Pembelajaran Berbasis Masalah Dengan Pembelajaran PAIKEM. UNIMED.

Sanjaya, D. R. H. W. (2016). Penelitian Tindakan Kelas. Prenada Media.

Siahaan, K. W. A., Haloho, U. N., Guk-Guk, M. P. A. R., \& Panjaitan, F. R. (2021). Implementation Of Discovery Learning Methods To Improve Science Skills In Kindergarten B Children. Jurnal Pendidikan Edutama, 8(1), 33-40.

Siahaan, K. W. A., Lumbangaol, S. T. P., Marbun, J., Nainggolan, A. D., Ritonga, J. M., \& Barus, D. P. (2021). Pengaruh Model Pembelajaran Inkuiri Terbimbing Dengan Multi Representasi Terhadap 
3088 The Effect of Problem-Based Learning Model During Pandemic On the Thematic Learning Outcomes of Students in Elementary School - Diana Falentina Simamora, Hisar Marulitua Manurung DOI : https://doi.org/10.31004/basicedu.v5i5.1242

Keterampilan Proses Sains Dan Penguasaan Konsep IPA. Jurnal Basicedu, 5(1), 195-205.

Siahaan, K. W. A., Manurung, H. M., \& Siahaan, M. M. (2021). Android-Based Learning Media Development Strategies During Pandemic Times To Improve Student Science Literature. International Journal Of Education And Humanities, 1(1), 34-42.

Simamora, R. E., Sidabutar, D. R., \& Surya, E. (2017). Improving Learning Activity And Students' Problem Solving Skill Through Problem Based Learning (PBL) In Junior High School. International Journal Of Sciences: Basic And Applied Research (IJSBAR), 33(2), 321-331.

Sulfemi, W. B., \& Mayasari, N. (2019). Peranan Model Pembelajaran Value Clarification Technique Berbantuan Media Audio Visual Untuk Meningkatkan Hasil Belajar IPS. Jurnal Pendidikan, 20(1), 5368.

Supriyanto, A., Hartini, S., Syamsudin, S., \& Sutoyo, A. (2019). Indicators Of Professional Competencies In Research Of Guidance And Counseling Teachers. Counsellia: Jurnal Bimbingan Dan Konseling, 9(1), $53-64$.

Wenger, E. (2014). Artificial Intelligence And Tutoring Systems: Computational And Cognitive Approaches To The Communication Of Knowledge. Morgan Kaufmann.

Widyatiningtyas, R., Kusumah, Y. S., Sumarmo, U., \& Sabandar, J. (2015). The Impact Of Problem-Based Learning Approach To Senior High School Students' Mathematics Critical Thinking Ability. Indonesian Mathematical Society Journal On Mathematics Education, 6(2), 30-38. 